\title{
Synthesis of Ni-P/Ni-P-W Nanocomposite Coating and its Tribological Resistance
}

\author{
A. Ansari, K. D. Singh, Sulaxna Sharma, Vijay Kumar, Vakul Bansal, Awanish Kumar Sharma
}

\begin{abstract}
The synthesized tungsten nanoparticles $(0.5 \mathrm{~g} / \mathrm{l}$, range 40 to $150 \mathrm{~nm}$ ) are dispersed randomly into electroless $\mathrm{Ni}-\mathrm{P}$ matrix for Ni-P-W nanocompositeplatings on an AISII040 grade steel substrate (MS). The thickness of these deposits is in range of 15 to 25 micrometer. The scanning electron microscope attached in permutation of energy dispersive spectroscopy furthermore $X$ ray diffraction techniques were exploited to analyze surface morphology, elemental symphony and phases of platings correspondingly. The results of these studies reveal successful fusion of tungsten nanoparticles as white globules into electroless Ni-P matrix and with those as-deposited platings have amorphous structure and heated platings $\left(400^{\circ} \mathrm{C}\right)$ have crystalline structure. Further Ni-P/Ni-P-W platings are investigated for microhardness by respective technique. The results of the studies corroborate that inclusion of tungsten nanoparticles into electroless Ni-P plating enhances the microhardness. The phase transformation initiation of amorphous nickel is headed toward nickel phosphide and crystalline nickel completely at $400^{\circ} \mathrm{C}$ which improved microhardness of nanocomposite Ni-P-W electrolessplatings.
\end{abstract}

Keywords: Electroless plating, Ni-P-W, characterization, microhardness.

\section{INTRODUCTION}

The electro less plating has accomplished extensive significance because of its uniform deposition, superior corrosion and tribological resistance. It is a proscribed chemical reduction method where copious chemical reactions occur concomitantly, in aqueous middling with no stream of electricity [1-3]. The dirt free metallic Ni, binary alloys as Ni-P, Co-P, Ni-B and Co-B furthermore ternary alloys Ni-P-B, Ni-Co-P, Ni-W-P etc were plated effectively moreover premeditated for their tribological properties. In last decade, extensive research has been done for codeposition of second segment nanoparticles into EL Ni-P medium and known as electro less nano composite platings. The particles such as $\mathrm{Si}_{3} \mathrm{~N}_{4}, \mathrm{SiC}, \mathrm{WC}, \mathrm{W}, \mathrm{ZnO}, \mathrm{ZrO}_{2}, \mathrm{TiO}_{2}$, and $\mathrm{Al}_{2} \mathrm{O}_{3}$ etc., are preferred for code position [4-15] for high hardness, corrosion and wear resistance.

Revised Manuscript Received on August 10, 2019.

*Corresponding author

A. Ansari, Research Scholars Department of Physics, GEU Dehradun and J.V Jain College Saharanpur

K.D. Singh, Research Scholars Department of Physics, GEU Dehradun and J.V Jain College Saharanpur

*Sulaxna Sharma, Assistant Professor, THDC, IHET Tehri. E-mail: sulaxnasharma@gmail.com

Vijay Kumar, Professor Department of Physics, Graphic Era Hil University Dehradun

Vakul Bansal, Professor Department of Physics, J.V Jain College Saharanpur

*Awanish Kumar Sharma, Professor Department of Physics, Graphic Era Deemed to be University Dehradun, India. E-mail: awanishiitr@gmail.com
Furthermore, soft particles as $\mathrm{MoS}_{2}, \mathrm{WS}_{2}$, PTFE, BN (h)) also graphite (C) afford super lubrication whilst built-in in EL Ni-P medium [16-24] because of having knack to avert connection between two buddy surfaces under un-lubricated environment. Elsewhere of Ni-P-X ( $\mathrm{X}=$ stiff particles) platings, the Ni-P-W platings illustrated very towering hardness furthermore wear conflict of substituting accessible hard chromium plating in automobile, aerospace and defense industries. Therefore in current investigation codeposition of synthesized $\mathrm{W}$ nanoparticles in EL Ni-P medium moreover its microhardness has been carried out.

\section{EXPERIMENTAL METHODS}

The electrolessplating (Figure 1) was done for two and half hour duration on mild steel (MS) specimens $(20 \mathrm{~mm} \times 20$ $\mathrm{mm} \times 03 \mathrm{~mm}$ ) which have chemical composition as $\mathrm{C}=$ $0.082 \%, \mathrm{Si}=0.034 \%, \mathrm{Mn}=0.33 \%, \mathrm{P}=0.006 \%, \mathrm{~S}=$ $0.024 \%, \mathrm{Cu}=0.05 \%$ and $\mathrm{Fe}=$ balance. Before depositions, the specimens were degreased with a solvent named acetone furthermore sluiced with deionized solvent. For sensitization and activations, specimens were dipped in $1 \% \quad \mathrm{SnCl}_{2}$ solution for 120 seconds and in $0.05 \% \mathrm{PdCl}_{2}$ solution for 60 seconds respectively. Bath symphony along with working surroundings for platings is specified in Table 1. Heating of $\mathrm{Ni}-\mathrm{P} / \mathrm{Ni}-\mathrm{P}-\mathrm{W}$ platings were conceded out in Argon ambiance at $400{ }^{0} \mathrm{C}$ for 01 hour time. The configuration of $\mathrm{W}$ fine particles, Ni-P/Ni-P-W platings were deliberated via $\mathrm{X}$ ray method with $\mathrm{CuK} \alpha$ radiation $(\lambda=0.154$ nanometer). Surface morphology of platings was scrutinized by SEM technique and qualitative elemental analysis of platings was done by EDAX/FESEMequipments. The crystallite middling extent of fine particles was premeditated via Scherer rule $(\mathrm{d}=0.9 \lambda / \beta \cos \theta)$ wherever, $\mathrm{d}_{h k l}$ is crystallite bulk upright to $(h k l)$ plane, $\lambda$ (nanometer) is wavelength of $\mathrm{X}$-ray beam used (i.e., $\lambda=1.51 \AA$ ), $\beta$ (radiun) is breadth of diffraction crest moreover $\theta$ is crest location. The FWHM is taken in support of $\beta$. The microhardness of platings was calculated by a microhardness tester.

TableA.1 Components of EL bath and their utility

\begin{tabular}{|c|c|c|}
\hline $\begin{array}{l}\text { Salt/ chemical } \\
\text { formulae }\end{array}$ & $\begin{array}{c}\text { Quantity } \\
\text { (g for } 100 \\
\text { ml) } \\
\end{array}$ & Functions \\
\hline Nickel sulphate & $04.17 \mathrm{~g}$ & source of $\mathrm{Ni}^{2+}$ ions \\
\hline $\begin{array}{l}\text { Tri } \quad \text { sodium } \\
\text { citrate }\end{array}$ & $04.73 \mathrm{~g}$ & $\begin{array}{l}\text { complexing driving } \\
\text { force, put off wild } \\
\text { release of } \mathrm{Ni}^{2+} \text { ions }\end{array}$ \\
\hline Sodium acetate & $02.54 \mathrm{~g}$ & $\begin{array}{l}\text { exertion as acidic } \\
\text { buffer to maintain } \mathrm{pH}\end{array}$ \\
\hline
\end{tabular}




\section{Synthesis of Ni-P/Ni-P-W Nanocomposite Coating and its Tribological Resistance}

\begin{tabular}{|c|c|c|}
\hline $\begin{array}{l}\mathrm{NaOH} / \text { acetic } \\
\text { acid10\% } \\
\text { solution }\end{array}$ & $\begin{array}{ll}\text { added in } \\
\text { drops }\end{array}$ & $\begin{array}{l}\text { keep up pH of solution } \\
\sim 5.6\end{array}$ \\
\hline $\begin{array}{l}\text { Sodium } \\
\text { hypophosphite }\end{array}$ & $02.43 \mathrm{~g}$ & $\begin{array}{l}\text { reducing chemical, } \\
\text { tender electrons to } \\
\mathrm{Ni}^{2+} \text { ions which on } \\
\text { accommodating } \\
\text { electrons get reduced } \\
\text { toward } \mathrm{Ni}^{0} \text { furthermore } \\
\text { deposited at catalytic } \\
\text { exterior }\end{array}$ \\
\hline $\begin{array}{l}\text { Sodium dodecyl } \\
\text { sulphate }\end{array}$ & $00.01 \mathrm{~g}$ & $\begin{array}{l}\text { increase wettability in } \\
\text { addition to surface } \\
\text { charge }\end{array}$ \\
\hline Lead acetate & $0.10 \mathrm{mg}$ & pour as a stabilizer \\
\hline $\begin{array}{l}\text { Synthesized W } \\
\text { nano particles } \\
40-150 \mathrm{~nm} \text { range }\end{array}$ & $00.05 \mathrm{~g}$ & $\begin{array}{l}\text { work as reinforcement } \\
\text { into the Ni-P matrix }\end{array}$ \\
\hline $\begin{array}{l}\text { Bath operating } \\
\text { conditions }\end{array}$ & - & $\begin{array}{l}\text { temperature } 86-88^{\circ} \mathrm{C} \text {; } \\
\text { pH 5.6; steady stirring }\end{array}$ \\
\hline $\begin{array}{l}\text { Annealing } \\
\text { temperature }\end{array}$ & $\begin{array}{l}400{ }^{\circ} \mathrm{C}, \mathrm{Ar} \\
\text { atmosphere, } \\
\text { 1 hour time }\end{array}$ & $\begin{array}{lr}\text { comprehend } & \\
\text { significance of heat } \\
\text { treatment } \\
\text { tribological on } \\
\text { corrosion resistance } \\
\end{array}$ \\
\hline
\end{tabular}

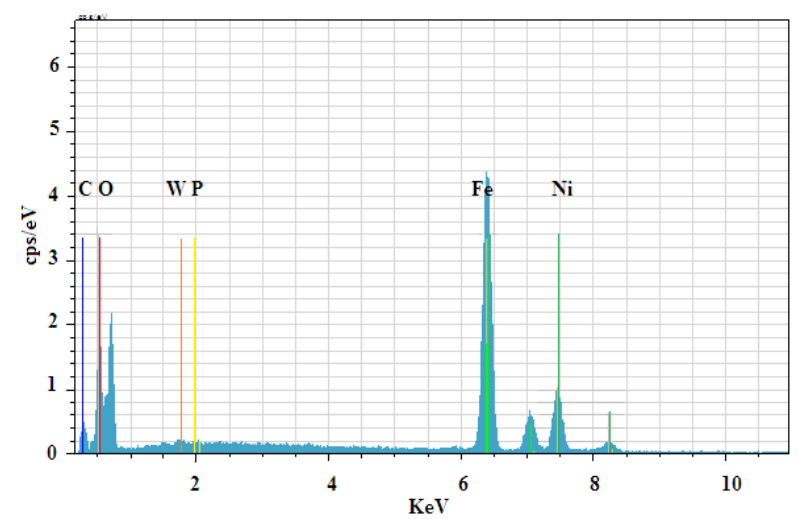

Fig. C.1: EDAX micrographs of Ni-P-W as-plated platings

Table B.1: EDAX values of EL Ni-P-W as-plated and heated specimens

\begin{tabular}{|c|c|c|}
\hline Elements & $\begin{array}{c}\text { \% Weight As- } \\
\text { Plated specimens }\end{array}$ & $\begin{array}{c}\text { \% Weight } \\
\text { Heated } \\
\text { specimens }\end{array}$ \\
\hline $\mathrm{Ni}$ & 80.64 & 79.54 \\
\hline $\mathrm{P}$ & 11.52 & 11.29 \\
\hline $\mathrm{W}$ & 03.73 & 03.89 \\
\hline $\mathrm{Fe}$ & 04.11 & 05.28 \\
\hline Total & 100.00 & 100.00 \\
\hline
\end{tabular}

Table C.1:Microhardness of different test specimens

\begin{tabular}{|l|l|}
\hline Specimens & Hardness $\left.\mathbf{~}_{\mathbf{H V}} \mathbf{2 5}\right)$ scale \\
\hline MS & 398.7 \\
\hline Ni-P as-plated & 493.2 \\
Ni-P heated at $400^{\circ} \mathrm{C}$ & 580.6 \\
\hline Ni-P-W as-plated & 697.9 \\
\hline Ni-P-W heated at $400^{\circ} \mathrm{C}$ & 944.5 \\
\hline
\end{tabular}

After heating no noteworthy transformation in topography of platings are observed. The microstructure of Ni-P platings has rotund globular configuration excluding morphology of complex Ni-P-W plating is diverse commencing Ni-P platings. In Ni-P-W platings, $\mathrm{W}$ nanoparticles are glowing discrete into Ni-P medium nevertheless at various spaces heavy coagulation of $\mathrm{W}$ nanoparticles which may be due to deposition of surfeit $\mathrm{W}$ nanoparticles on the surface of platings. The stoicheometric fraction of rudimentary analysis (wt. \%) dogged by EDAX (Figure 3) method is prearranged in Table 2. By EDAX method, in heated Ni-P$\mathrm{W}$ platings dwindle in absorption of $\mathrm{Ni}$ on accumulation of $\mathrm{W}(0.5 \mathrm{gpl})$ and $\mathrm{P} \%$ vestiges nearly alike and an curious boost of $\mathrm{Fe}$ has been also observed.It has been also reported in [25-33] that elemental allocation in plating affects plating properties furthermore outlined an inter-diffusion stratum. The occurrence of momentous quantity and consistent allocation of $\mathrm{Fe}$ bared via EDAX scrutiny, credited to dispersion of plating elements towards edge of plating along with mild steel [34-40]. The XRD spectra of as-plated Ni-P platings set apart with diffraction $\mathrm{Ni}$ (111) and iron peaks, which match up to amorphous phases of alloys (JCPDS000031044).

(c)

Fig.B.1: SEM micrographs of (a) Ni-P as-plated (b) Ni-P$\mathrm{W}$ as-plated platings (c) Ni-P-W heated platings

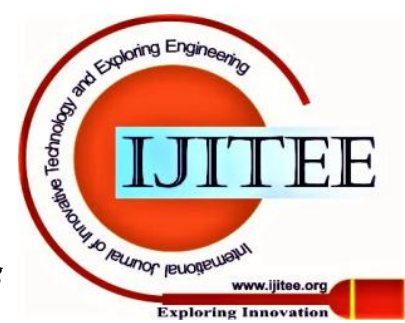


The amorphousness of platings is too justified by presence of phosphorous about $11 \%$ weight (Table2). The max out of iron is for reason of mild steel. The analogous spectrum of as-plated Ni-P-W platings bared amorphousness of Ni-P medium alongside very diminutive attribute diffraction climax of $\mathrm{W}$ nanoparticles due to presence of lower amounts of W $(0.5 \mathrm{gpl})$ nanoparticles in composite platings. Annealing on $400{ }^{\circ} \mathrm{C}$ for 01 hour time in Argon milieu is naked a shrink in streak expansion and intensity of crests which indicate transformation of amorphous nickel and $\mathrm{Ni}_{\mathrm{x}} \mathrm{P}_{\mathrm{y}}$ segments in crystalline $\mathrm{Ni}, \mathrm{Ni}_{3} \mathrm{P}$ and $\mathrm{W}$ phases. The microhardness of Ni-P/Ni-P-W platings in as-plated and heated environments was determined by a microhardness tester with residence time of 20 seconds under a $25 \mathrm{gf}$ load. The hardness of mild steel substrate and Ni-P/Ni-P-W plated specimens are in succeeding sort Ni-P-W (heated) $>$ Ni-P-W (as-plated) $>$ Ni-P > MS. The results of microhardness put forward that addition of $\mathrm{W}$ nanoparticles into Ni-P platings put in drastically to microhardness of specimens as W nanoparticles are the hardest nanoparticles.

\section{CONCLUSIONS}

A dull grimy nanocomposite plating of Ni-P-W on mild steel substrates is experienced. Electroless Ni-P/Ni-P-W platings illustrate evidence of good adherence on mild steel. The microhardness values of Ni-P-W platings are enhanced significantly on incorporation of $\mathrm{W}$ nanoparticles into electroless Ni-P matrix.

\section{ACKNOWLEDGEMENT}

Authors acknowledge for GEU, GEHU, IITR, THDCIHET and Wadia Institute Dehradun for providing support and experimental support in finishing of current experimental study.

\section{REFERENCES}

1. A. Brenner and G. Riddell, Res. Natl. US Bur. Stand. 37 (1946) 31.

2. A. Brenner, D. E. Couch and E.K. Williams, J. Res. Nat. Bur. Stand. 44 (1950) 10.

3. R.C. Agarwala, Ph D thesis, Department of Metallurgical and Materials Engineering, University of Roorkee (presently IIT, Roorkee), (1987).

4. P.K. Datta, P.B. Bedingfield, D.B. Lewis and P.B. Wells, 'Structure and phase changes accompanying treatment of electroless $\mathrm{Ni}-\mathrm{B}$ alloy coating', Conf. Proc. 2nd Int. Electroless Nickel Conference Solihull (1991) 139-153.

5. A. Srivastava, S. Mohan, V. Agarwala and R.C. Agarwala, Z. Metallkd. 83(1992) 251-253.

6. K.H. Krishnan, J. Praveen, M. Ganesan, P.M. Kavimani, S. John and K.N. Srinivasan,Mater Perform 45 (2006)36-39.

7. J.N. Balaraju and K.S. Rajam, Surf Coat Technol 195(2005)154-161.

8. D.H. Kim, K. Aoki and O. Takano, J. Electrochem. Soc. 142 (1995) 3763-3767.

9. L. Wang, L. Zhao, B. Zhang, S. Liao, Y. OnYang and W. Hu, Z. Metallkd. 88 (1997) 945-948

10. S.B Sharma, PhD Thesis. 'Synthesis and tribological characterization of Ni-P based electroless composite coatings'. IIT Roorkee, India, 2002.

11. J. Sudagar, J. Lian and W. Sha, J. of Alloys and Compounds, 571 (2013) 183-204.

12. I. Apachitei, F.D. Tichelaar, J. Duszczyk and L. Katgerman,Surf. Coat. Technol., 149 (2002) 263-278.

13. G. Jiaqiang, L. Lei, W. Yating, S. Bin and H. Wenbin, Surf. Coat. Technol., 200 (2006) 5836-5842.
14. Y.S. Huang, X.T. Zeng, I. Annergren and F.M. Liu, Surf. Coat. Technol., 167 (2003) 207-211.

15. D. Dong, X.H. Chen, W.T. Xiao, G.B. Yang and P.Y. Zhang, Appl. Surf. Sci., 255 (2009) 7051-7055.

16. T. Rabizadeh and S.R. Allahkaram, Mater. Des.,vol. 32 (2011)133138 ,.

17. W. Chen, W. Gao and Y. He, Surf. Coat. Technol., 204(2010) 2493 2498.

18. Balaraju J.N., Rajam K.S., Electroless Deposition of Ni-Cu-P, Ni-W$\mathrm{P}$ and Ni-W-Cu-P Alloys, J. Surf.Coat. Technol., 2005, 195, 154 161.

19. M.D. Ger and B.J. Hwang, Mater. Chem. Phys., 76 (2002) 38-45.

20. P.R. Ebdon, Plat. Surf. Finish. 75(1988) 65-68.

21. A. Ramalho and J.C. Miranda, Wear, 259 (2005) 828-834.

22. W.X. Chen, J.P. Tu, Z.D. Xu, R. Tenne, R. Rosenstveig, W.L. Chen, H.Y. GanandTu J.P., (2002) Wear and friction of Ni-P electroless composite coating including inorganic fullerene-like $\mathrm{WS}_{2}$ nanoparticles. Adv. Eng. Mater.,4 pp. 686-690.

23. O.A. Leon, M.H. Staia and H.E. Hintermann, Surf. Coat. Technol., 200 (2005) 1825-1829.

24. N. Feldstein, G.O. Mallory and J.B. Hajdu, 'Electroless Plating: Fundamentals and Applications', American Electroplaters and Surface Finishers Society, Orlando, Florida,(Eds.) (1990) 269.

25. S. Sharma,C.K. Saini, S. Sharmaand V. Agarwala, J. Mater. Environ. Sci.5 (5) (2014) 1667-1670.

26. S. Sharma, S. Sharma, P. Agarwala, R. Garg and P. Gopinath,Advanced Materials Research, 585 (2012) 512-516.

27. T. Rabizadeh, S. R. Allahkaram and A. Zarebidaki, Materials and Design, 31 (2010) 3174-3179.

28. P. K. Roy, J. Mater. Sci. Res., 1 (2012) 28-34.

29. A. Zoikis-Karathanasis, E.A. Pavlatou and N. Spyrellis, The effect of heat treatment on the structure and hardness of pulse electrodeposited NiP-WC composite coatings, ElectrochimicaActa, 54 (2009) 25632470 .

30. J.N. Balaraju, C. Anandan and K.S. Rajam, Applied Surface Science, 250 (2005) 88-97.

31. J.N. Balaraju, T.S.N. Sankara Narayanan and S.K. Seshadri, J. Appl. Electrochem.,(2003) 807-816. (Balaraju J.N., Narayana TSN Sankara, Seshadri S.K., (2003), "Electroless Ni-P composite coatings", J ApplElectrochem, Vol. 33, pp. 807-816.)

32. S. R. Allahkaram, R. FaeziAlivand and M. S. Bakhsh, Iranian J. Mater. Sci. Engg., 10 (2013) 11-17.

33. A Babanejhad, M. Hashemi, Y. Rahmatallahpur and Sh A Nozad, Bull. Mater. Sci., 35 (2012) 561-566.

34. S.M.A. Shibli, B. Jabeera, R.I. Anupama, Surf. Coat. Technol. 200 (2006) 3903

35. S.M.A. Shibli, B. Jabeera, R.I. Anupama, Appl. Surf. Sci. 253 (2006) 1644-1648.

36. Sarika Sharma, Development of Electroless Ni-P-ZnO Nanocomposite Coatings, Thesis GEU 2015.

37. M. Bouanani, F. Cherkaoui, R. Fratesi, G. Roventi, and G. Barucca, J. Appl. Electrochem.,29, 637 (1999).

38. B. Veeraraghavan, B. Haran, S.P. Kumaraguru and B. Popov, J. Electrochem. Soc., 150 (4) (2003) B131-B139.

39. A.S. Hamdy, M.A. Shoeib, H. Hady, O.F. Abdel Salam, Surface \& Coatings Technology 202 (2007) 162-171.

40. E. Valova, I. Georgiev, S. Armyanov, J.L. Delplancke, B. Tachev, T Tsa-Cheva, J. Dille, J. Electrochem. Soc. 148 (4) (2001) 266.

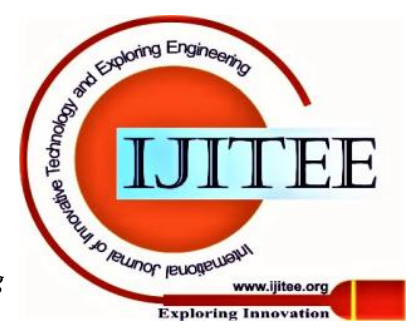

